\title{
Sistem Pendukung Keputusan Dengan Menggunakan Metode Electre Dalam Merekomendasikan Dosen Berprestasi Bidang Ilmu Komputer (Study Kasus di AMIK \& STIKOM Tunas Bangsa)
}

\author{
Siti Sundari ${ }^{1}$, Anjar Wanto ${ }^{2}$, Saifullah ${ }^{3}$, Indra Gunawan ${ }^{4}$ \\ 1,2,3,4 Jurusan Sistem Informasi, STIKOM Tunas Bangsa, Pematangsiantar Sumatera Utara \\ ${ }^{1}$ Mahasiswa STIKOM Tunas Bangsa, Pematangsiantar Sumatera Utara \\ ${ }^{2,3,4}$ Dosen STIKOM Tunas Bangsa, Pematangsiantar Sumatera Utara \\ $1,2,3 \mathrm{Jln}$. Jenderal Sudirman blok A. No. 1/2/3 Pematangsiantar \\ e-mail: *sitisundari@gmail.com, ${ }^{2}$ anjarwanto@amiktunasbangsa.ac.id, \\ 3saifullah@amiktunasbangsa.ac.id, indragunawan@amiktunasbangsa.ac.id
}

\begin{abstract}
Abstrak - Dosen merupakan tenaga akademik yang bertugas merencanakan dan melaksanakan proses pembelajaran, menilai hasil pembelajaran, melakukan pembimbingan dan pelatihan, serta melakukan penelitian serta pengabdian kepada masyarakat. AMIK \& STIKOM Tunas Bangsa merupakan pelopor sarjana komputer di Pematangsiantar yang melaksanakan suatu agenda pemilihan dosen berprestasi. Kegiatan ini bertujuan untuk memberikan penghargaan kepada Dosen sesuai dengan UU No 14 tahun 2005 tentang Guru dan Dosen, Pasal 51 Ayat (1) Butir b, bahwa Dosen berhak mendapatkan promosi dan penghargaan sesuai dengan kinerja akademiknya. Melalui penghargaan ini setiap dosen diharapkan akan termotivasi untuk menjadi lebih baik dan selalu meningkatkan kualitas. Adapun permasalahan yang dihadapi yaitu adanya kesulitan dalam menentukan keputusan siapa yang terpilih menjadi dosen berprestasi dengan kriteria-kriteria yang memiliki sifat subjektif atau tidak pasti dengan cepat. Untuk mengatasi permasalahan tersebut maka dirancang sebuah sistem pendukung keputusan (SPK) untuk pemilihan dosen berprestasi menggunakan Metode ELECTRE. Metode Electre merupakan metode pengambilan keputusan multikriteria berdasarkan pada konsep Outranking dengan menggunakan perbandingan berpasangan dari alternative-alternatif berdasarkan setiap kriteria yang sesuai. Adapun kriteria yang dipakai yaitu: Penilaian Mahasiswa, Penilaian Dosen sejawat, Penilaian Pimpinan/Manajemen, Kualifikasi Pendidikan, Penelitian, Jurnal, Pelatihan, Seminar, Pengabdian kepada Masyarakat, dan Jabatan Akademik. Hasil akhir dari penelitian ini diharapkan dapat membantu merekomendasikan dosen yang layak di beri penghargaan dari segi prestasi yang diperolehnya. Dari alternatif dan kriteria yang ada maka yang mendapat nilai tertinggi ialah Dedy Hartama, Agus Perdana Windarto dan Solikhun.
\end{abstract}

Kata kunci : Dosen, SPK, Metode Electre, Berprestasi dan Ilmu Komputer

\section{PENDAhUluan}

Perguruan tinggi berkewajiban menyelenggarakan pendidikan, penelitian dan pengabdian kepada masyarakat. Salah satu unsur dalam penyelenggaraan pendidikan tinggi adalah dosen. Dosen merupakan tenaga akademik yang bertugas merencanakan dan melaksanakan proses pembelajaran, menilai hasil pembelajaran, melakukan pembimbingan dan pelatihan, serta melakukan penelitian serta pengabdian kepada masyarakat. Berdasarkan Undang-undang Republik Indonesia No. 14 tahun 2005 tentang Guru dan Dosen, Pasal 51 Ayat (1) Butir b, bahwa dosen berhak mendapatkan promosi dan penghargaan sesuai dengan kinerja akademiknya [1].

Sistem penghargaan terkait dengan aspirasi dan motivasi di kalangan dosen ini diharapkan menjadi salah satu cara dalam pengembangan manajemen akademik di AMIK \& STIKOM Tunas Bangsa Pematangsiantar. Selain itu sistem penghargaan merupakan salah satu unsur penting dan memiliki peran dalam menumbuh kembangkan suasana akademik. Sistem 
penghargaan ini harus sejalan dan sesuai dengan harkat dan martabat dosen sebagai penggali dan pengembang ilmu, teknologi, peneliti dan pengabdi pada masyarakat. Merujuk pada pemikiran di atas, sudah selayaknya pemberian penghargaan diberikan kepada dosen yang memiliki prestasi yang dibanggakan oleh Perguruan Tingginya dalam bidang tridarma Perguruan Tinggi. Pemberian penghargaan akan mendorong dosen untuk berprestasi secara lebih produktif.

Pada penelitian ini dibangun Sistem Pendukung Keputusan dengan menggunakan metode analisis pengambilan keputusan multikriteria yaitu Electre. Menggunakan metode Electre karena permasalahan ini sesuai dan cocok pada konsep perangkingan berdasarkan alternatif dan kriteria yang telah ditetapkan. Metode Electre ini dapat digunakan pada kondisi dimana alternatif yang kurang sesuai dengan kriteria dieliminasi dan alternatif yang sesuai dapat dihasilkan. Keluaran dari sistem ini berupa laporan hasil perankingan dosen berprestasi di AMIK \& STIKOM Tunas Bangsa.

\section{METODE PENELITIAN}

\subsection{Dosen}

Dosen adalah pendidik profesional dan ilmuwan dengan tugas utama mentranformasikan, mengembangkan, dan menyebarluaskan ilmu pengetahuan,teknologi dan seni melalui pendidikan, penelitian dan pengabdian kepada masyarakat(UU-RI No. 1 tahun 2005 pasal 1(2) Tentang Guru dan Dosen)[2].

\subsection{Sistem Pendukung Keputusan(SPK)}

Sistem Pendukung Keputusan (SPK) adalah salah satu cara mengorganisir informasi yang dimaksudkan untuk digunakan dalam membuat keputusan. Ada yang mendefinisikan bahwa system pendukung keputusan merupakan suatu pendekatan untuk mendukung pengambilan keputusan.Sistem pendukung keputusan menggunakan data, memberikan antarmuka pengguna yang mudah dan dapat menggabungkan pemikiran pengambil keputusan [3]

\subsection{Elimination Et Choix Traduisant la Realite (ELECTRE)}

Electre merupakan salah satu metode pengambilan keputusan multi kriteria berdasarkan pada konsep Outranking dengan menggunakan perbandingan berpasangan dari alternatifalternatif berdasarkan setiap kriteria yang sesuai [4]. Metode Electre digunakan pada kondisi dimana alternatif yang kurang sesuai dengan kriteria dieliminasi, dan alternatif yang sesuai dapat dihasilkan. Dengan kata lain, Electre digunakan untuk kasus-kasus dengan banyak alternatif namun hanya sedikit kriteria yang dilibatkan. Suatu alternatif dikatakan mendominasi alternatif yang lainnya jika satu atau lebih kriterianya melebihi (dibandingkan dengan kriteria dari alternatif yang lain) dan sama dengan kriteria lain yang tersisa [5]

Langkah-langkah yang dilakukan dalam penyelesaian masalah menggunakan metode Electre adalah sebagai berikut:

1. Normalisasi matriks keputusan

Dalam prosedur ini, setiap atribut diubah menjadi nilai comparable. Setiap normalisasi dari nilai $\mathrm{x}_{\mathrm{ij}}$ dapat dilakukan dengan rumus:

$$
r_{i j}=\frac{x_{i j}}{\sqrt{\sum_{i=1}^{m} x^{2}{ }_{i j}}} \text {, untuk } i=1,2,3 \ldots, m \text { dan } j=1,2,3 \ldots, n .
$$

Sehingga didapat matriks $\mathrm{R}$ hasil normalisasi,

$$
R=\left[\begin{array}{cccc}
r_{11} & r_{12} & \cdots & r_{1 n} \\
r_{21} & r_{22} & \cdots & r_{2 n} \\
\vdots & & & \\
r_{m 1} & r_{m 2} & \cdots & r_{m n}
\end{array}\right]
$$


$\mathrm{R}$ adalah matriks yang telah di normalisasi, dimana $\mathrm{m}$ menyatakan alternatif, $\mathrm{n}$ menyatakan kriteria dan $r_{i j}$ adalah normalisasi pengukuran pilihan dari alternatif ke-i dalam hubungannya dengan kriteria ke-j.

2. Pembobotan pada matriks yang telah dinormalisasi

Setelah dinormalisasi, setiap kolom dari matriks $\mathrm{R}$ dikalikan dengan bobot-bobot $\left({ }^{W_{j}}\right)$ yang ditentukan oleh pembuat keputusan. Sehingga $\mathrm{V}=\mathrm{RW}$ yang ditulis sebagai:

$$
\left[\begin{array}{cccc}
v_{11} & v_{12} & \cdots & v_{1 n} \\
v_{21} & v_{22} & \cdots & v_{2 n} \\
\vdots & & & \\
v_{m 1} & v_{m 2} & \ldots & v_{m n}
\end{array}\right]\left[\begin{array}{cccc}
w_{1} r_{11} & w_{1} r_{12} & \cdots & w_{n} r_{1 n} \\
w_{1} r_{21} & w_{2} r_{22} & \cdots & w_{n} r_{2 n} \\
\vdots & & & \\
w_{1} r_{m 1} & w_{2} r_{m 2} & \ldots & w_{n} r_{m n}
\end{array}\right]
$$

Dimana W adalah

$$
W=\left[\begin{array}{cccc}
w_{1} & 0 & \cdots & 0 \\
v_{21} & w_{2} & \cdots & 0 \\
\vdots & & & \\
0 & 0 & \cdots & w_{n}
\end{array}\right]
$$

3. Menentukan concordance dan discordance

Untuk setiap pasang dari alternatif $k$ dan $l(k, l=1,2,3, \ldots, m$ dan $k \neq l)$ kumpulan kriteria $J$ dibagi menjadi dua subsets, yaitu concordance dan discordance. Bilamana sebuah kriteria dalam suatu alternatif termasuk concordance adalah :

$$
C_{k l}=\left\{j, v_{k j} \geq v_{i j}\right\}_{\text {,untuk }} i=1,2,3, \ldots \text {. }
$$

Sebaliknya, komplementer dari himpunan concordance adalah himpunan discordance, yaitu bila:

$D_{k l}=\left\{j, v_{k j}<v_{i j}\right\}$,untuk $i=1,2,3, \ldots$.

4. Hitung matriks concordance dan discordance

a. Menghitung matriks concordance

Untuk menentukan nilai dari elemen-elemen pada matriks concordance adalah dengan menjumlahkan bobot-bobot yang termasuk pada himpunan concordance, secara matematis:

$C_{k l}=\sum_{j \in C_{k l}} w_{j}$

b. Menghitung matriks discordance

Untuk menentukan nilai dari elemen-elemen pada matriks discordance adlah dengan membagi maksimum selisih kriteria yang termasuk ke dalam himpunan bagian discordance dengan maksimum selisih nilai seluruh yang ada, secara matematis:

$$
d_{k l}=\frac{\max \left\{\left|v_{k j}-v_{l j}\right|\right\} j \in D_{k l}}{\max \left\{\left|v_{k j}-v_{l j}\right|\right\} \forall j}
$$

A. Menentukan matriks dominan concordance dan discordance

a. Menentukan matriks dominan concordance 
Matriks $\mathrm{F}$ sebagai matriks dominan concordance dapat dibangun dengan bantuan nilai threshold, yaitu membandingkan setiap nilai elemen matriks concordance dengan nilai threshold.

$$
C_{k l} \geq c
$$

Dengan nilai threshold (c) adalah:

$$
c=\frac{\sum_{k=1}^{m} \sum_{l=1}^{m} c_{k l}}{m(m-1)}
$$

Sehingga elemen matriks $\mathrm{F}$ ditentukan sebagai berikut:

$$
f_{k l}=\left\{\begin{array}{lll}
1, j i k a & c_{k l} \geq c \\
0, j i k a & c_{k l}<c
\end{array}\right\}
$$

b. Menentukan matriks dominan discordance

Untuk membangun matriks dominan discordance juga menggunakan bantuan nilai threshold, yaitu :

$$
D_{k l} \geq d
$$

Sehingga elemen matriks $\mathrm{G}$ ditentukan sebagai berikut:

$$
g_{k l}=\left\{\begin{array}{ll}
1, j i k a & d_{k l}<d \\
0, j i k a & d_{k l} \geq d
\end{array}\right\}
$$

c. Menentukan aggregate dominance matriks

Langkah selanjutnya adalah menentukan aggregate dominance matrix sebagai matriks $E$, yang setiap elemennya merupakan perkalian antara elemen matriks $F$ dengan elemen matriks $G$, sebagai berikut :

$$
E_{k l}=f_{k l} \times g_{k l}
$$

d. Eliminasi alternatif yang less favourable

Matriks $E$ memberikan urutan pilihan dari setiap alternatif, yaitu bila $e k l=1$ maka alternatif $A k$ merupakan pilihan yang lebih baik dari pada $A l$. Sehingga baris dalam matriks $E$ yang memiliki jumlah $e k l=1$ paling sedikit dapat dieliminasi. Dengan demikian alternatif terbaik adalah yang mendominasi alternatif lainnya [6]

\section{HASIL DAN PEMBAHASAN}

Adapun kriteria yang dipakai dalam merekomendasikan dosen berprestasi pada Amik \& Stikom Tunas Bangsa ialah Penilaian Mahasiswa (C1), Penilaian Dosen Sejawa t(C2), Penilaian Atasan/manajement (C3), Kualifikasi Pendidikan (C4), Jumlah Penelitian Non DPRM (C5), Jumlah Penelitian DPRM (C6), Jumlah Paper Skala Nasional Tidak Terakreditasi (C7), Jumlah Paper Skala Nasional Terakreditasi (C8), Jumlah Paper Skala Internasional Tidak Bereputasi (C9), Jumlah Paper Skala Internasional Bereputasi (C10), Pelatihan Khusus yang diikuti (C11), Seminar yang diikuti (C12), Pengabdian kepada Masyarakat Non DPRM (C13), Pengabdian kepada Masyarakat DPRM (C14), dan Jabatan Akademik (C15).

Dalam penelitian ini dipakai data sampel 7 dosen berprestasi dalam bidang ilmu komputer sebagai alternatif untuk melakukan perhitungan manual dengan metode Electre, yaitu :

$\mathrm{A}_{1}=$ Dedy Hartama,S.T,M.Kom

$\mathrm{A}_{2}=$ Agus Perdana Windarto, M.Kom

$\mathrm{A}_{3}=$ M.Ridwan Lubis, M.Kom

$\mathrm{A}_{4}=$ Eka Irawan, M.Kom

$\mathrm{A}_{5}=$ Indra Gunawan, M.Kom

$\mathrm{A}_{6}=$ Sundari Retno Andani, M.Kom

$\mathrm{A}_{7}=$ Solikhun, M.Kom

Sedangkan tingkat kepentingan kriteria (bobot preferensi) juga dinilai antara 0 dan 1 , yaitu Sangat Baik $(0,9)$, Baik $(0,7)$, Cukup $(0,5)$, Kurang $(0,3)$ dan Sangat kurang $(0,2)$ 
Tabel 1 Menentukan rating kecocokan setiap alternatif pada setiap kriteria

\begin{tabular}{|l|l|l|l|l|l|l|l|l|l|l|l|l|l|l|l|}
\hline & C1 & C2 & C3 & C4 & C5 & C6 & C7 & C8 & C9 & C10 & C11 & C12 & C13 & C14 & C15 \\
\hline A1 & 0,9 & 0,7 & 0,9 & 0,5 & 0,9 & 0,2 & 0,9 & 0,2 & 0,75 & 0,2 & 0,9 & 0,75 & 0,75 & 0,2 & 0,5 \\
\hline A2 & 0,7 & 0,7 & 0,7 & 0,5 & 0,9 & 0,4 & 0,9 & 0,2 & 0,9 & 0,4 & 0,9 & 0,4 & 0,4 & 0,2 & 0,3 \\
\hline A3 & 0,7 & 0,7 & 0,7 & 0,5 & 0,5 & 0,2 & 0,2 & 0,2 & 0,2 & 0,2 & 0,4 & 0,35 & 0,4 & 0,2 & 0,3 \\
\hline A4 & 0,7 & 0,7 & 0,7 & 0,5 & 0,5 & 0,2 & 0,2 & 0,2 & 0,2 & 0,2 & 0,4 & 0,35 & 0,4 & 0,2 & 0,25 \\
\hline A5 & 0,7 & 0,7 & 0,7 & 0,5 & 0,5 & 0,2 & 0,4 & 0,2 & 0,2 & 0,2 & 0,4 & 0,35 & 0,4 & 0,2 & 0,25 \\
\hline A6 & 0,7 & 0,7 & 0,7 & 0,5 & 0,5 & 0,2 & 0,2 & 0,2 & 0,2 & 0,2 & 0,4 & 0,35 & 0,4 & 0,2 & 0,3 \\
\hline A7 & 0,7 & 0,7 & 0,7 & 0,5 & 0,5 & 0,4 & 0,9 & 0,2 & 0,4 & 0,2 & 0,4 & 0,35 & 0,4 & 0,2 & 0,5 \\
\hline
\end{tabular}

Tabel 1 menunjukkan rating kecocokan dari setiap alternatif pada setiap kriteria. Karena setiap nilai yang diberikan pada setiap alternatif di setiap kriteria merupakan nilai kecocokkan dimana nilai terbesar adalah terbaik, maka semua kriteria yang diberikan diasumsikan sebagai kriteria keuntungan. Pengambil keputusan memberikan bobot preferensi sebagai:

$\mathrm{W}=\{0.5,0.5,0.5,0.7,0.5,0.9,0.7,0.9,0.5,0.9,0.7,0.7,0.7,0.9,0.9\}$

Langkah-langah selanjutnya yang harus dilakukan adalah:

a. Normalisasi matriks keputusan.

$$
\begin{aligned}
& r_{11}=\frac{x_{11}}{\sqrt{x_{11^{2}}+x_{21^{2}}+x_{31^{2}}++x_{41^{2}}+x_{51^{2}}+x_{61^{2}}+x_{71^{2}}}} \\
& r_{11}=\frac{0,9}{\sqrt{0,9^{2}+0,7^{2}+0,7^{2}+0,7^{2}+0,7^{2}+0,7^{2}+0,7^{2}}} \\
& r_{11}=\frac{0,9}{\sqrt{0,81+0,49+0,49+0,49+0,49+0,49+0,49}} \\
& r_{11}=\frac{0,9}{3,84} \\
& r_{11}=0,2344
\end{aligned}
$$

Tabel 2. Hasil Normalisasi Matriks Keputusan

\begin{tabular}{|r|r|r|r|r|r|r|r|r|r|r|r|r|r|r|}
\hline 0,234 & 0,192 & 0,234 & 0,25 & 0,304 & 0,294 & 0,321 & 0,455 & 0,399 & 0,357 & 0,359 & 0,493 & 0,439 & 0,454 & 0,4367 \\
\hline 0,182 & 0,192 & 0,182 & 0,25 & 0,304 & 0,588 & 0,321 & 0,455 & 0,478 & 0,714 & 0,3589 & 0,263 & 0,234 & 0,454 & 0,262 \\
\hline 0,182 & 0,192 & 0,182 & 0,25 & 0,169 & 0,294 & 0,071 & 0,455 & 0,106 & 0,357 & 0,159 & 0,229 & 0,234 & 0,454 & 0,262 \\
\hline 0,182 & 0,192 & 0,182 & 0,25 & 0,169 & 0,294 & 0,071 & 0,455 & 0,106 & 0,357 & 0,159 & 0,229 & 0,234 & 0,454 & 0,2183 \\
\hline 0,182 & 0,192 & 0,182 & 0,25 & 0,169 & 0,294 & 0,143 & 0,455 & 0,106 & 0,357 & 0,159 & 0,229 & 0,234 & 0,454 & 0,2183 \\
\hline 0,182 & 0,192 & 0,182 & 0,25 & 0,169 & 0,294 & 0,071 & 0,455 & 0,106 & 0,357 & 0,159 & 0,229 & 0,234 & 0,454 & 0,262 \\
\hline 0,182 & 0,192 & 0,182 & 0,25 & 0,169 & 0,588 & 0,321 & 0,455 & 0,213 & 0,357 & 0,159 & 0,229 & 0,234 & 0,454 & 0,4367 \\
\hline
\end{tabular}

\section{b. Pembobotan pada matriks yang telah dinormalisasi}

$$
V_{11}=W_{1} R_{11}
$$

\begin{tabular}{|c|c|c|c|c|c|c|c|c|c|c|c|c|c|c|}
\hline 0,117 & 0,096 & 0,117 & 0,175 & 0,152 & 0,265 & 0,225 & 0,409 & 0,199 & 0,321 & 0,251 & 0,345 & 0,307 & 0,409 & 0,393 \\
\hline 0,091 & 0,096 & 0,091 & 0,175 & 0,152 & 0,529 & 0,225 & 0,409 & 0,239 & 0,643 & 0,251 & 0,184 & 0,1637 & 0,409 & 0,236 \\
\hline 0,091 & 0,096 & 0,091 & 0,175 & 0,084 & 0,265 & 0,05 & 0,409 & 0,053 & 0,321 & 0,112 & 0,161 & 0,1637 & 0,409 & 0,236 \\
\hline 0,091 & 0,096 & 0,091 & 0,175 & 0,084 & 0,265 & 0,05 & 0,409 & 0,053 & 0,321 & 0,112 & 0,161 & 0,1637 & 0,409 & 0,196 \\
\hline 0,091 & 0,096 & 0,091 & 0,175 & 0,084 & 0,265 & 0,1 & 0,409 & 0,053 & 0,321 & 0,112 & 0,161 & 0,1637 & 0,409 & 0,196 \\
\hline 0,091 & 0,096 & 0,091 & 0,175 & 0,084 & 0,265 & 0,05 & 0,409 & 0,053 & 0,321 & 0,112 & 0,161 & 0,1637 & 0,409 & 0,236 \\
\hline 0,091 & 0,096 & 0,091 & 0,175 & 0,084 & 0,529 & 0,225 & 0,409 & 0,106 & 0,321 & 0,112 & 0,161 & 0,1637 & 0,409 & 0,393 \\
\hline
\end{tabular}$$
V_{11}=0,5 * 0,2344
$$$$
V_{11}=0,117
$$

Hasil perkalian bobot preferensi setiap kriteria dengan matriks keputusan yang telah dinormalisasi dapat dilihat pada tabel berikut ini:

Tabel 3. Pembobotan Pada Matriks setelah normalisasi

c. Menentukan himpunan concordance dan disordance index.

1. Concordance

Sebuah kriteria dalam suatu alternatif termasuk concordance jika:

$$
C_{k l}=\left\{j, y_{k j} \geq y_{l j}\right\}, \text { untuk } j=1,2,3, \ldots, n
$$


Hasil concordance yang didapat, yaitu:

$\mathrm{C}_{12}=\{1,2,3,4,5,7,8,11,12,13,14,15\}$

$\mathrm{C}_{13}=\{1,2,3,4,5,6,7,8,9,10,11,12,13,14,15\}$

$\mathrm{C}_{14}=\{1,2,3,4,5,6,7,8,9,10,11,12,13,14,15\}$

$\mathrm{C}_{15}=\{1,2,3,4,5,6,7,8,9,10,11,12,13,14,15\}$

$\mathrm{C}_{16}=\{1,2,3,4,5,6,7,8,9,10,11,12,13,14,15\}$

$\mathrm{C}_{17}=\{1,2,3,4,5,7,8,9,10,11,12,13,14,15\}$

$\mathrm{C}_{21}=\{2,4,5,6,7,8,9,10,11,14\}$

$\mathrm{C}_{23}=\{1,2,3,4,5,6,7,8,9,10,11,12,13,14,15\}$

$\mathrm{C}_{24}=\{1,2,3,4,5,6,7,8,9,10,11,12,13,14,15\}$

$\mathrm{C}_{25}=\{1,2,3,4,5,6,7,8,9,10,11,12,13,14,15\}$

$\mathrm{C}_{26}=\{1,2,3,4,5,6,7,8,9,10,11,12,13,14,15\}$

$\mathrm{C}_{27}=\{1,2,3,4,5,7,8,9,10,11,12,13,14\}$

$\mathrm{C}_{31}=\{2,4,6,8,10,14\}$

$\mathrm{C}_{32}=\{1,2,3,4,8,13,14,15\}$

$\mathrm{C}_{34}=\{1,2,3,4,5,6,7,8,9,10,11,12,13,14,15\}$

$\mathrm{C}_{35}=\{1,2,3,4,5,6,8,9,10,11,12,13,14,15\}$

$\mathrm{C}_{36}=\{1,2,3,4,5,6,7,8,9,10,11,12,13,14,15\}$

$\mathrm{C}_{37}=\{1,2,3,4,5\}$

$\mathrm{C}_{41}=\{2,4,6,8,10,14\}$

$\mathrm{C}_{42}=\{1,2,3,4,8,9,13,14\}$

$\mathrm{C}_{43}=\{1,2,3,4,5,6,7,8,9,10,11,12,13,14\}$

$\mathrm{C}_{45}=\{1,2,3,4,5,6,8,9,10,11,12,13,14,15\}$

$\mathrm{C}_{46}=\{1,2,3,4,5,6,7,8,9,10,11,12,13,14\}$

$\mathrm{C}_{47}=\{1,2,3,4,5,8,10,11,12,13,14\}$

$\mathrm{C}_{51}=\{2,4,6,8,10,14\}$

$\mathrm{C}_{52}=\{1,2,3,4,8,13,14\}$

$\mathrm{C}_{53}=\{1,2,3,4,5,6,7,8,9,10,11,12,13,14\}$

$\mathrm{C}_{54}=\{1,2,3,4,5,6,7,8,9,10,11,12,13,14,15\}$

$\mathrm{C}_{56}=\{1,2,3,4,5,6,7,8,9,10,11,12,13,14\}$

$\mathrm{C}_{57}=\{1,2,3,4,5,8,10,11,12,13,14\}$

$\mathrm{C}_{61}=\{2,4,6,8,10,14\}$

$\mathrm{C}_{62}=\{1,2,3,4,8,13,14,15\}$

$\mathrm{C}_{63}=\{1,2,3,4,5,6,7,8,9,10,11,12,13,14,15\}$

$\mathrm{C}_{64}=\{1,2,3,4,5,6,7,8,9,10,11,12,13,14,15\}$

$\mathrm{C}_{65}=\{1,2,3,4,5,6,8,9,10,11,12,13,14,15\}$

$\mathrm{C}_{67}=\{1,2,3,4,5,8,10,11,12,13,14\}$

$\mathrm{C}_{71}=\{2,4,6,7,8,10,14,15\}$

$\mathrm{C}_{72}=\{1,2,3,4,6,7,8,13,14,15\}$

$\mathrm{C}_{73}=\{1,2,3,4,5,6,7,8,9,10,11,12,13,14,15\}$

$\mathrm{C}_{74}=\{1,2,3,4,5,6,7,8,9,10,11,12,13,14,15\}$

$\mathrm{C}_{75}=\{1,2,3,4,5,6,7,8,9,10,11,12,13,14,15\}$

$\mathrm{C}_{76}=\{1,2,3,4,5,7,8,9,10,11,12,13,14,15\}$

\section{Discordance}

Sebuah kriteria dalam suatu alternatif termasuk discordance jika:

$D_{k l}=\left\{j, y_{k j}<y_{l j}\right\}$, untuk $j=1,2,3, \ldots, n$

Hasil discordance yang didapat, yaitu:

$\mathrm{D}_{12}=\{6,9,10\}$

$\mathrm{D}_{13}=\{\}$

$\mathrm{D}_{14}=\{\}$

$\mathrm{D}_{15}=\{\}$

$\mathrm{D}_{16}=\{\}$

$\mathrm{D}_{17}=\{6\}$

$D_{21}=\{1,3,12,13,15\}$

$\mathrm{D}_{23}=\{\}$

$\mathrm{D}_{24}=\{\}$

$\mathrm{D}_{25}=\{\}$

$\mathrm{D}_{26}=\{\}$

$\mathrm{D}_{27}=\{15\}$

$\mathrm{D}_{31}=\{1,3,5,7,9,11,12,13,15\}$ 
$\mathrm{D}_{32}=\{5,6,7,9,10,11,12\}$

$\mathrm{D}_{34}=\{\}$

$\mathrm{D}_{35}=\{7\}$

$\mathrm{D}_{36}=\{\}$

$D_{37}=\{6,7,8,9,10,11,12,13,14,15\}$

$\mathrm{D}_{41}=\{1,3,5,7,9,11,12,13\}$

$\mathrm{D}_{42}=\{5,6,7,9,10,11,12,15\}$

$\mathrm{D}_{43}=\{15\}$

$\mathrm{D}_{45}=\{7\}$

$\mathrm{D}_{46}=\{15\}$

$\mathrm{D}_{47}=\{6,7,9,15\}$

$D_{51}=\{1,3,5,7,9,11,12,13,15\}$

$\mathrm{D}_{52}=\{5,6,7,9,10,11,12,15\}$

$\mathrm{D}_{53}=\{15\}$

$\mathrm{D}_{54}=\{\}$

$\mathrm{D}_{56}=\{15\}$

$\mathrm{D}_{57}=\{6,7,9,11,12,13,15\}$

$\mathrm{D}_{61}=\{1,3,5,7,9,11,12,13,15\}$

$\mathrm{D}_{62}=\{5,6,7,9,10,11,12\}$

$\mathrm{D}_{63}=\{\}$

$\mathrm{D}_{64}=\{\}$

$\mathrm{D}_{65}=\{7\}$

$\mathrm{D}_{67}=\{6,7,9,15\}$

$D_{71}=\{1,3,5,7,9,11,12,13\}$

$\mathrm{D}_{72}=\{5,9,10,11,12\}$

$\mathrm{D}_{73}=\{\}$

$\mathrm{D}_{74}=\{\}$

$\mathrm{D}_{75}=\{\}$

$\mathrm{D}_{76}=\{\}$

\section{d. Menghitung matriks concordance dan discordance.}

1. Menghitung matriks concordance

$$
\begin{aligned}
c_{k l} & =\sum_{j c_{w}} w_{j} \\
C_{12} & =W_{1}+W_{2}+W_{3}+W_{4}+W_{5}+W_{7}+W_{8}+W_{11}+W_{12}+W_{13}+W_{14}+W_{15} \\
& =0,5+0,5+0,5+0,7+0,5+0,7+0,9++0,7+0,7+0,7+0,9+0,9=8,2
\end{aligned}
$$

Sehingga diperoleh matriks concordance yang dinyatakan dalam tabel di bawah ini:

Tabel 4. Matriks Concordance

\begin{tabular}{|r|r|r|r|r|r|r|}
\hline \multicolumn{1}{l|}{} & 8,2 & 10,5 & 10,5 & 10,5 & 10,5 & 9,6 \\
\hline 7,2 & - & 10,5 & 10,5 & 10,5 & 10,5 & 9,6 \\
\hline 4,8 & 5,6 & - & 10,5 & 9,8 & 10,5 & 2,7 \\
\hline 4,8 & 4,7 & 9,6 & - & 9,8 & 9,6 & 8,9 \\
\hline 4,8 & 4,7 & 9,6 & 10,5 & - & 9,6 & 8,9 \\
\hline 4,8 & 5,6 & 10,5 & 10,5 & 9,8 & - & 8,9 \\
\hline 6,4 & 7,2 & 10,5 & 10,5 & 10,5 & 10,5 & - \\
\hline
\end{tabular}

2. Menghitung Matriks discordance

$$
\begin{aligned}
& d_{k l}=\frac{\left\{\max \left(v_{m n}-v_{m n-\mathrm{ln}}\right)\right\} ; m, n \varepsilon D_{k l}}{\left\{\max \left(v_{m n}-v_{m n-1 \mathrm{n}}\right)\right\} ; m, n=1,2,3, \ldots}
\end{aligned}
$$

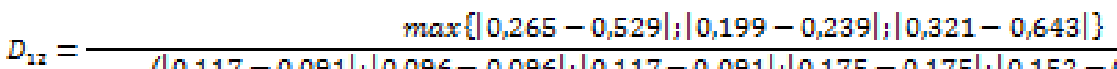

$$
\begin{aligned}
& \max \left\{\begin{array}{c}
|0,117-0,091| ;|0,096-0,096| ;|0,117-0,091| ;|0,175-0,175| ;|0,152-0,152| ;|0,265-0,529| ; \\
|0,225-0,225| ;|0,409-0,409| ;|0,199-0,239| ;|0,321-0,643| ;|0,251-0,251| ;|0,345-0,184| ; \\
|0,307-0,164| ;|0,409-0,409| ;|0,393-0,236|
\end{array}\right) \\
& D_{12}=\frac{\max \{0,322\}}{\max \{0,026 ; 0 ; 0,026 ; 0 ; 0 ; 0,273 ; 0 ; 0 ; 004 ; 0,322 ; 0 ; 0,161 ; 0,143 ; 0 ; 0,157\}} \\
& D_{12}=\frac{0,322}{0,322}
\end{aligned}
$$


$D_{12}=1$

Sehingga diproleh matriks discordance:

Tabel 5. Matriks Discordance

\begin{tabular}{|l|l|r|r|r|r|r|}
\hline- & 1 & 0 & 0 & 0 & 0 & 1 \\
\hline 0,489 & - & 0 & 0 & 0 & 0 & 0,49 \\
\hline 0,855 & 0,321 & - & 0 & 1 & 0 & 0,9 \\
\hline 0,729 & 0,321 & 1 & - & 1 & 1 & 0,74 \\
\hline 1 & 0,321 & 0,79 & 0 & - & 0,187 & 0,74 \\
\hline 0,855 & 0,321 & 0 & 0 & 1 & - & 0,59 \\
\hline 0,541 & 0,321 & 0 & 0 & 0 & 0 & - \\
\hline
\end{tabular}

e. Menentukan matriks dominan concordance dan disordance

1. Menghitung matriks dominan concordance

Nilai threshold (ㄷ) adalah

$$
\begin{aligned}
& \begin{array}{r}
8,2+10,5+10,5+10,5+10,5+9,6+7,2+10,5+10,5+10,5+10,5+9,6+4,8+5,6+10,5 \\
+9,8+10.5+2,7+4,8+4,7+9,6+9,8+9.6+8,9+4,8+4,7+9,6+10,5+9,6+8,9+4,8+5,6 \\
+10,5+10,5+9,8+8,9+6,4+7,2+10,5+10,5+10,5+10,5
\end{array} \\
& \underline{c}=\frac{7(7-1)}{\underline{c}=\frac{363,7}{42}} \\
& \underline{c}=8,66
\end{aligned}
$$

Sehingga elemen matriks $\mathrm{F}$ ditentukan sebagai berikut :

$f_{k l}=1$, jika $c_{k l} \geq \underline{c} \operatorname{dan} f_{k l}=0$, jika $c_{k l}<\underline{c}$

Sehingga matriks dominan concordance adalah

Tabel 6. Matriks Dominan Concordance

\begin{tabular}{|r|r|r|r|r|r|r|}
\hline- & 0 & 1 & 1 & 1 & 1 & 1 \\
\hline 0 & - & 1 & 1 & 1 & 1 & 1 \\
\hline 0 & 0 & - & 1 & 1 & 1 & 0 \\
\hline 0 & 0 & 1 & - & 1 & 1 & 1 \\
\hline 0 & 0 & 1 & 1 & - & 1 & 1 \\
\hline 0 & 0 & 1 & 1 & 1 & - & 1 \\
\hline 0 & 0 & 1 & 1 & 1 & 1 & - \\
\hline
\end{tabular}

2. Menghitung matriks dominan disordance

Nilai threshold (d) adalah

$$
\begin{array}{r}
\underline{d}=\frac{\begin{array}{r}
1+0+0+0+0+1+0,489+0+0+0+0+0,489+0,855+0,321+0+1+0+0,898 \\
+0,729+0,321+1++1+1+0,742+1+0,321+0,786+0+0,187+0,742 \\
+0,855+0,321+0+0+1+0,594+0,541+0,321+0+0+0+0
\end{array}}{7(7-1)} \\
\underline{d}=\frac{17,52}{42}
\end{array}
$$$$
\underline{d}=0,417
$$

Sehingga elemen matriks $g$ ditentukan sebagai berikut :

$g_{k l}=0, j i k a c_{k l} \geq \underline{d}$ dan $g_{k l}=1$, jika $c_{k l}<\underline{d}$

Sehingga matriks dominan disordance jika di tampilkan dalam tabel adalah sebagai berikut:

Tabel 7. Matriks Dominan Disordance

\begin{tabular}{|l|l|l|l|l|l|l|}
\hline- & 0 & 1 & 1 & 1 & 1 & 0 \\
\hline 0 & - & 1 & 1 & 1 & 1 & 0 \\
\hline 0 & 1 & - & 1 & 0 & 1 & 0 \\
\hline 0 & 1 & 0 & - & 0 & 0 & 0 \\
\hline 0 & 1 & 0 & 1 & - & 1 & 0 \\
\hline
\end{tabular}




\begin{tabular}{|l|l|l|l|l|l|l|}
0 & 1 & 1 & 1 & 0 & - & 0 \\
\hline 0 & 1 & 1 & 1 & 1 & 1 & - \\
\hline
\end{tabular}

\section{f. Menentukan aggregate dominance matrix.}

Rumus umum untuk anggota matriks aggregate dominance adalah $E_{k l}=f_{k l} \times g_{k l}$

Sehingga matriks aggregate dominance jika di tampilkan dalam tabel adalah sebagai berikut:

Tabel 8. Matriks Aggregate Dominance

\begin{tabular}{|r|r|r|r|r|r|r|}
\hline- & 0 & 1 & 1 & 1 & 1 & 0 \\
\hline 0 & - & 1 & 1 & 1 & 1 & 0 \\
\hline 0 & 0 & - & 1 & 0 & 1 & 0 \\
\hline 0 & 0 & 0 & - & 0 & 0 & 0 \\
\hline 0 & 0 & 0 & 1 & - & 1 & 0 \\
\hline 0 & 0 & 1 & 1 & 0 & - & 0 \\
\hline 0 & 0 & 1 & 1 & 1 & 1 & - \\
\hline
\end{tabular}

\section{g. Eliminasi alternatif yang less favourable}

Matriks E memberikan urutan pilihan dari setiap alternatif, yaitu bila $e_{k l}=1$ maka alternatif $A_{k}$ merupakan alternatif yang lebih baik daripada $A_{1}$. Sehingga, baris dalam matriks $E$ yang memiliki jumlah $e_{\mathrm{kl}}=1$ paling sedikit dapat dieliminasi. Pada tabel 8 , baris dengan nama Dedy Hartama, Agus Perdana Windarto dan Solikhun yang memiliki elemen $\mathrm{e}_{\mathrm{kl}}=4$. Dari hasil perhitungan di atas dosen dengan nama Dedy Hartama, Agus Perdana Windarto dan Solikhun mempunyai nilai $\mathrm{e}_{\mathrm{kl}}=1$ dengan jumlah yang sama. Maka pemilihan dosen berprestasi diambil dari nilai $\mathrm{e}_{\mathrm{kl}}=4$ yang paling dekat dari kanan. Artinya baris dengan nama Dosen yang memiliki nilai $\mathrm{e}_{\mathrm{kl}}=1$ paling jauh dari arah kanan dapat dieliminasi.Dengan demikian, berdasarkan hasil perhitungan manual dan program,dapat disimpulkan bahwa berdasarkan metode ELECTRE pemilihan dosen berprestasi terbaik adalah Dedy Hartama, Agus Perdana Windarto dan Solikhun

\section{KESIMPULAN}

Berdasarkan penelitian yang dilakukan oleh penulis maka dapat disimpulkan bahwa metode ELECTRE merupakan suatu metode penentuan prioritas yang bisa dibilang cukup sederhana. Dalam urutan prioritas tebaik dipengaruhi oleh tipe preferensi yang digunakan. Dengan membandingkan nilai alternatif menggunakan metode ELECTRE maka didapat urutan alternatif terbaik dengan hasil yang objektif. Berdasarkan hasil penelitian juga dapat disimpulkan bahwa Dedy Hartama,S.T,M.Kom, Agus Perdana Windarto,M.Kom dan Solikhun,M.Kom yang berhak direkomendasikan menjadi dosen berprestasi dalam bidang ilmu komputer di Amik \& Stikom Tunas Bangsa

\section{DAFTAR PUSTAKA}

[1] Undang-undang No 14 tahun 2005 tentang Guru dan Dosen

[2] Puspito Rini, Puput., 2015. Sistem Pendukung Keputusan Pemilihan Dosen Terbaik Berbasis Web Dengan Metode SAW (Studi Kasus : STMIK Global Tangerang). Jurnal Sisfotek Global, No.2, Vol.5

[3] Agus Perdana Windarto, "Implementasi Metode Topsis Dan Saw Dalam Memberikan Reward Pelanggan”, Klik-Kumpulan Jurnal Ilmu Komputer, 4 (1), pp. 88-101

[4] Fahmi Setiawan, Sistem Pendukung Keputusan SNMPTN Jalur Undangan dengan Metode ELECTRE, Skripsi Program Studi Ilmu Komputer, Universitas Lambung Mangkurat, Banjarbaru, 2015. 
[5] Kusumadewi dkk. 2006. Fuzzy Multi-Attribute Decision Making (Fuzzy $M A D M)$. Yogyakarta: Graha Ilmu.

[6] Fahmi Setiawan, Sistem Pendukung Keputusan SNMPTN Jalur Undangan dengan Metode ELECTRE, Skripsi Program Studi Ilmu Komputer, Universitas Lambung Mangkurat, Banjarbaru, 2015. 